УДК 629.113

UDC 629.113

Гандзюк М.О., Гандзюк Д.М.

Луиький національний технічний університет

\title{
ФАКТОРИ, ЩО ВПЛИВАЮТЬ НА СТІЙКІСТЬ РУХУ АВТОМОБІЛІВ І АВТОПОӤЗДІВ У ГАЛЬМІВНОМУ РЕЖИМІ ТА КРИТЕРІЇ ЇЇ ОЦІНКИ
}

\begin{abstract}
3 огляду на зростання інтенсивності руху на сучасних автомагістралях, необхідно підвищити безпеку транспортних засобів для уникнення аварійних ситуацій, що несуть за собою погіршення здоров'я людей та значні матеріальні втрати при пошкодженні транспортних засобів та вантажів. Особливо гостро це питання стосується автомобільних поїздів, процес руху та гальмування яких набагато складніший ніж в одиничних автомобілів. Необхідно щоб гальмівна система дозволяла регулювати швидкість руху автопоїзда у широкому діапазоні, протидіяла заносам, а також унеможливлювала складання ланок транспортного засобу та його зіткнення з іншими автомобілями, тобто забезпечувала відповідну стійкість. Водій повинен максимально контролювати поведінку транспортного засобу під часу руху, а за потреби швидко та безпечно зупинити його.

Поліпшення експлуатаційних властивостей автопоїздів у сучасних умовах руху $\epsilon$ одним iз пріоритетних завдань для забезпечення високого рівня безпеки їх експлуатації з максимальною ефективністю використання. Досягнення даних вимог можливе лише за умови врахування можливих змін технічного стану автопоїздів у процесі експлуатації. Зокрема, значну увагу слід відвести змінам, які можуть відбутися у гальмівній системі ланок автопоїзда, що можуть спричинити порушення оптимальних показників регулювання й розподілу гальмівних сил по осях та бортах транспортного засобу, що неминуче призводить до втрати стійкості його руху навіть при незначних швидкостях, особливо при максимальному завантаженні.

Зважаючи на це у роботі проведено аналіз факторів, що впливають на стійкість руху автомобілів $\mathrm{i}$ автопоїздів у гальмівному режимі та основних критеріїв стійкості і ефективності гальмування транспортних засобів, а також огляд нормативних документів, що їх регламентують.

Ключові слова: стійкість, гальмівний режим, гальмівний шлях, ефективність гальмування, питома гальмівна сила, усталене сповільнення, динамічний коридор, бокове ковзання, пробуксовування, смуга руху, напрям руху, лінійне відхилення, кутове відхилення, кут складання.
\end{abstract}

\section{ВСТУП}

Для досягнення високих показників продуктивності використання автопоїздів при здійсненні вантажоперевезень необхідно створити умови для їх експлуатації з максимальною ефективністю, тобто із максимальним завантаженням та при русі на максимальних швидкостях. Для цього, в першу чергу, потрібно забезпечити дотримання даними транспортними засобами основних експлуатаційних властивостей, що визначають безпеку руху. Серед найбільш важливих техніко-експлуатаційних властивостей автопоїздів, що забезпечують безпеку їх руху, варто виокремити стійкість, зокрема у гальмівному режимі. Адже втрата стійкості часто приводить до створення дорожньо-транспортних пригод, що супроводжуються травмуванням та значними матеріальними втратами.

\section{АНАЛІЗ ЛІТЕРАТУРНИХ ДАНИХ ТА ПОСТАНОВКА ПРОБЛЕМИ}

Проблемі дослідження стійкості руху автомобіля та автопоїзда присвячено багато робіт, оскільки вона $\epsilon$ важливою характеристикою, яка визначає його поведінку під впливом зовнішніх факторів. Дослідженню стійкості транспортних засобів при гальмуванні присвячені роботи Антонова Д.А., Волкова В.П., Закина Я.Х., Косолапова Г.М., Литвинова А.С., Ляпунова О.М., Малюгіна П.М., Певзнера Я.М., Подригало М.А., Полякова В.М., Ревіна О.О., Ревіна С.О., Сахна В.П., Солнцева О.М., Соцкова Д.О., Фалькевича Б.С., Хамова І.В., Хачатурова А.А., Чудакова Є. О. та інших науковців.

Дослідженню маневреності та стійкості руху автопоїздів компонувальної схеми «автомобільтягач - двовісний підкатний візок - тривісний напівпричіп» присвячені роботи [1], [2].

Проведений аналіз робіт вітчизняних та зарубіжних науковців дозволив з'ясувати, що в своїх працях дослідники не використовують єдино прийнятого тлумачення поняття стійкості транспортного засобу в гальмівному режимі руху. В більшості, кожен з них акцентує увагу на певних окремих особливостях даної властивості. Проте, незважаючи на певне розходження у тлумаченні терміну, усі автори вважають стійкість важливою характеристикою транспортного засобу, яка дозволяє йому зберігати заданий напрямок руху, не відхилятися від нього під впливом прикладених сил та моментів.

\section{ЦІЛЬ ТА ЗАДАЧІ ДОСЛІДЖЕННЯ}

Метою роботи $є$ аналіз факторів, що впливають на стійкість руху автомобілів і автопоїздів у 
гальмівному режимі та критеріїв ï оцінки.

\section{РЕЗУЛЬТАТИ ДОСЛІДЖЕНЬ}

Дослідники виділяють різні фактори, які порушують стійкість руху транспортних засобів у гальмівному режимі.

Зокрема, у роботі [3] автор, аналізуючи фактори, які впливають на стійкість автомобіля при гальмуванні, поділяє їх на дві групи: зовнішні та внутрішні.

Зовнішні: дорожні фактори, пов'язані зі зміною погодно-кліматичних умов, які впливають на зчеплення шин 3 опорною поверхнею, та провокують появу ділянок з поперечною неоднорідністю коефіцієнта зчеплення; наявність поперечних нахилів дорожнього покриття; вплив відцентрових сил, які діють на криволінійних ділянках доріг; вплив аеродинамічних сил, прикладених в боковому напрямку.

Внутрішні: фактори, обумовлені технічним станом конструктивних елементів автомобіля.

У роботі [4] виділено три основні групи факторів:

- зовнішні, які залежать від погодно-кліматичних умов та стану дороги;

- внутрішні, які залежать від технічного стану автомобіля,

- конструктивні, що залежать від досконалості конструкції гальмівної системи автомобіля.

У роботі [5] автор вважає, що порушення стійкості автомобіля може виникнути при визначених умовах його взаємодії з опорною поверхнею, а також внаслідок інерційних та аеродинамічних явищ. До таких умов автор відносить нерівності дорожньої поверхні, наявність поздовжніх та поперечних нахилів, нерівномірність сил зчеплення, а також різницю у величині дотичних реакцій на правому та лівому колесах.

У роботі [6] критеріями стійкості автор обрав кути повороту автомобіля-тягача та причепів у горизонтальній площині та відхилення автопоїзда за межі «безпечного коридору», шириною 3 м. На основі проведеного дослідження автор встановив, що нерівномірність впливу гальмівних моментів спричиняє втрату стійкості автопоїзда при гальмуванні з початкових швидкостей, які відповідають експлуатаційним нормам для даного транспортного засобу. Найбільш нестійкою ланкою досліджуваного автопоїзда $є$ автомобіль-тягач, який першим виходив за межі «безпечного коридору» у всіх досліджених випадках гальмування. Автор вважає, що для оцінки розподілу гальмівних сил по осях транспортного засобу можна використовувати поняття питомих гальмівних сил осей автомобіля або ланок автопоїзда. Оптимальний розподіл гальмівних сил по осях транспортного засобу відбуватиметься тоді, коли питомі гальмівні сили всіх осей будуть рівними.

У ході проведених досліджень науковці, окрім факторів, що впливають на стійкість, виокремили ряд показників, які дозволяють характеризувати стійкість автомобілів при гальмуванні, проводити іiі оцінку.

Зокрема у роботі [9] автор виокремив два критерії для її оцінки: початок бокового ковзання осі, яке супроводжується пробуксовуванням і боковим ковзанням внутрішнього колеса та початок пробуксовування і бокового ковзання внутрішнього колеса осі.

У роботі [5] у якості критерію стійкості при заносі запропоновано використовувати критичну кутову швидкість $\omega_{\text {кр }}$ :

$$
\omega_{\text {кр }}=\varphi g / v,
$$

де $\varphi$ - коефіцієнт зчеплення коліс з дорогою;

$v$ - швидкість руху транспортного засобу.

На основі проведених досліджень автор з'ясував, що при $\omega \leq \omega_{\text {кр }}$ рух транспортного засобу стійкий, а при $\omega>\omega_{\text {кр }}$ рух нестійкий.

У роботі [10] автор запропонував такі критерії для оцінки стійкості та ефективності гальмування автомобіля (рисунок 1):

$-\delta$ - лінійне відхилення від заданої смуги руху;

- $\delta^{*}$ - лінійне відхилення від лінії напрямку руху;

- $\gamma$ - кутове відхилення від лінії напрямку руху;

$-\mathrm{S}_{\mathrm{T}}-$ гальмівний шлях;

$-\Delta \gamma-$ порівняльний критерій по кутовому відхиленні;

$-\Delta \delta-$ порівняльний критерій по лінійному відхиленні;

$-\varepsilon_{\mathrm{s}}-$ порівняльний критерій ефективності гальмування;

$-\Delta \omega_{1}-$ приріст кутової швидкості автомобіля через 1 секунду після початку гальмування;

$-\Delta \gamma_{1}-$ приріст курсового кута автомобіля через 1 секунду після початку гальмування. 


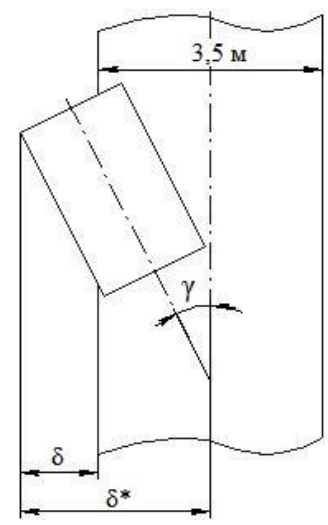

Рисунок 1 - Критерії оцінки стійкості транспортного засобу при гальмуванні

На основі аналізу умов руху автомобілів по автомагістралях встановлено [3], що найбільш повно їх положення характеризує динамічний коридор, який утворюється максимально віддаленими точками кузова автомобіля при його гальмуванні. Оцінка технічної стійкості автомобіля на основі порівняння отриманого при дослідженні динамічного коридору iз коридором, визначеним нормативними документами, дозволить наблизити встановлені обмеження до вимог щодо безпеки pyxy.

У роботі [11] використано такі критерії для оцінки стійкості автомобіля:

-лінійне відхилення автомобіля від заданої траєкторії;

-кутове відхилення автомобіля від заданої траєкторії;

-час спрацювання гальмівних механізмів

-відхилення центра мас автомобіля від заданої траєкторії.

На основі проведених досліджень автор стверджує, що при дорожніх випробуваннях стійкості руху автомобіля при гальмуванні можна обмежитися лише оцінкою відхилення центра його мас від заданої траєкторії.

На основі аналізу вітчизняних та міжнародних нормативних документів, які регламентують гальмівні якості транспортних засобів у роботі [4] виділено п'ять критеріїв стійкості та ефективності гальмування автомобілів:

-лінійне відхилення транспортного засобу від заданої траєкторії руху;

-кутове відхилення транспортного засобу від заданого напрямку руху;

-кут складання автопоїзда;

-величина гальмівного шляху;

-максимальне і середнє сповільнення.

Досліджуючи вплив нерівномірності дії гальмівних механізмів на показники стійкості автопоїзда при гальмуванні у роботі [6] в якості критеріїв стійкості використано кути повороту автомобіля-тягача та причепів у горизонтальній площині та відхилення автопоїзда від заданого «безпечного коридору» шириною 3 м.

На сьогодні гальмівні властивості транспортних засобів та показники їх стійкості у гальмівному режимі регламентують такі нормативні документи:

- ДСТУ 2886:94 “Автотранспортні засоби. Гальмівні властивості. Терміни та визначення”;

- ДСТУ 3736:98 “Стійкість дорожньо-транспортних засобів. Терміни та визначення”;

- ДСТУ 3310:96 “Засоби транспортні дорожні. Стійкість. Методи визначення основних параметрів випробуванням";

- ДСТУ UN/ECE R 13-09:2002 (Правила ЄЕК ООН № 13) "Сдині технічні приписи щодо офіційного схвалення типу транспортних засобів категорій М N та О стосовно гальмування";

- ДСТУ 3649:2010 "Колісні транспортні засоби. Вимоги щодо безпечності технічного стану та методи контролювання" [12-16].

Зокрема, з їх використанням встановлюються основні терміни та визначення, що стосуються гальмівних властивостей, визначаються особливості проведення досліджень та відбувається нормування гальмівних властивостей автомобілів та автопоїздів.

Згідно із нормативним документом [12] основними критеріями стійкості та ефективності гальмування транспортних засобів є: 
-лінійне відхилення від коридору руху шириною 3,5 м;

-загальна питома гальмівна сила $\gamma_{г}$; коефіцієнт нерівномірності гальмівних сил осі;

-тривалість спрацювання гальмівної системи;

-усталене сповільнення ј уст;

-гальмівний шлях $\mathrm{S}_{\Gamma}$;

-початкова швидкість гальмування $\mathrm{V}_{0}$;

-час гальмування $\mathrm{t}_{\Gamma}$.

\section{ОБГОВОРЕННЯ РЕЗУЛЬТАТІВ ДОСЛІДЖЕНЬ}

Проведений аналіз дозволив з'ясувати, що проблема стійкості руху автомобільних поїздів у гальмівному режимі досліджена достатньо повно. Проте, меншою мірою досліджені питання прогнозування стійкості автопоїзда в процесі гальмування з урахуванням змін, що відбуваються в ходовій частині в умовах експлуатації, а також змін у гальмівній системі. Зокрема, більш детального аналізу потребує дослідження впливу характеру розподілу гальмівних сил по осях та бортах автопоїзда та величини і характеру перекосу осей ланок автопоїзда на показники стійкості його руху в гальмівному режимі. Особливої уваги потребує вивчення спільного впливу даних факторів.

\section{ВИСНОВОК}

На основі аналізу факторів, що впливають на стійкість руху автомобілів і автопоїздів у гальмівному режимі можна стверджувати, що основними з них є зовнішні, які залежать від погоднокліматичних умов та стану дороги, внутрішні, які залежать від технічного стану автомобіля та конструктивні, що залежать від досконалості конструкції гальмівної системи автомобіля.

В якості критеріїв оцінки стійкості руху автомобілів і автопоїздів у гальмівному режимі можна використати критерії, зазначені в ДСТУ 3649:2010.

При виборі критеріїв оцінки стійкості руху варто враховувати тип транспортного засобу та його конструктивні особливості.

\section{ПЕРЕЛІК ДЖЕРЕЛ ПОСИЛАННЯ}

1. Гандзюк М.О., Селезньов Е.Л., Гандзюк Д.М. Розробка плоскої математичної моделі руху модульного триланкового причіпного автопоїзда у складі «автомобіль-тягач - двовісний підкатний візок 3 неповоротними осями (dolly) - тривісний напівпричіп // Наукові нотатки: Міжвузівський збірник, випуск 55, Луцьк: Редакційно видавничий відділ Луцького НТУ, 2016 - С.72-79.

2. Сахно В.П. Математичне моделювання триланкових автопоїздів в поздовжній, вертикальній і поперечній площинах / В.П. Сахно, В.М. Поляков, В.М. Глінчук // Вісник Донецької академії автомобільного транспорту. Науковий журнал, 2013. - Вип. 3. - С.73-84.

3. Ревин А.А. Повышение эффективности, устойчивости и управляемости при торможении автотранспортних средств: дис. на соиск. учен. степ. д-ра техн. наук / А.А. Ревин. - Волгоград, 1983. - 601 с.

4. Соцков Д.А. Повышение активной безопасности автотранспортних средств при торможении: дис. на соиск. учен. степ. д-ра техн. наук / Д.А. Соцков. - Владимир, 1988. - 410 с.

5. Певзнер Я. М. Теория устойчивости автомобиля / Я.М. Певзнер. - М.: Машгиз, 1947. - 159 с.

6. Солнцев А.Н. Совершенствование процеса торможения автопоезда большой габаритной длины: дис. на соискан. учен. степ. канд. техн. наук / А.Н. Солнцев. - М., 2004. - 169 с.

7. Стоянов Г. А. Обобщенный критерий для оценки безопасности движения автомобиля при торможении / Г.А. Стоянов, В.В. Иванов, В.А. Иларионов // Автомобильная промышленность. -1979. - №8. - C. 19-21.

8. Кравчук П.М. Нормування гальмівних властивостей колісних транспортних засобів в Україні / П.М. Кравчук, Р.Ю. Нілов, Ю.В. Бабін // Науково-виробничий журнал Автомобільний транспорт: У реаліях міжнародного права. - 2014. - № 2(238). - С. 8-10.

9. Чудаков Е.А. Боковая устойчивость автомобиля при торможении / Е.А. Чудаков. - М.: Машгиз, 1952. -183 с.

10. Хамов И.В. Повышение устойчивости легкового автомобиля при торможении путем применения противозаносных систем: дис. на соискан. учен. степ. канд. техн. наук / И.В. Хамов. - М., 1989. $-210 \mathrm{c}$.

11 Малюгин П.Н. Возможности и пути улучшения устойчивости движения автомобиля при торможении: дис. на соискан. учен. степ. канд. техн. наук / П.Н. Малюгин. - Омск, 1985. -229c.

12. Колісні транспортні засоби. Вимоги щодо безпечності технічного стану та методи контролювання: ДСТУ 3649:2010. - [Чинний від 2011-07-01]. - Офіц. вид. - К.: Держспоживстандарт України, 2011. - 28 с. - (Національний стандарт України). 
13. Автотранспортні засоби. Гальмівні властивості. Терміни та визначення : ДСТУ 2886:94. - [Чинний від 1996-01-01]. - К. : Держстандарт України, 1996. - 28 с. - (Державний стандарт України).

14. Стійкість дорожньо-транспортних засобів. Терміни та визначення : ДСТУ 3736:98. - [Чинний від 1999-07-01]. - Офіц. вид. - К. : Держстандарт України, 1999. - III, 11 с. - (Державний стандарт України).

15. Засоби транспортні дорожні. Стійкість. Методи визначення основних параметрів випробуванням : ДСТУ 3310:96. - [чинний від 1997-01-01]. - Офіц. вид. - К. : Держстандарт України, 1996. - 10 с. - (Державний стандарт України).

16. ДСТУ UN/ECE R 13-09:2002. Сдині технічні приписи щодо офіційного схвалення типу транспортних засобів категорій М N та О стосовно гальмування: Правила СЕК ООН № 13. - [Чинні від 14.01.2008]. - Женева : Свропейська Економічна Комісія Організації Об’єднаних націй, 2008. $276 \mathrm{c}$.

\section{REFERENCES}

1. Gandzyuk, M.O., \& Seleznev, E.L., \& Gandzyuk, D.M. (2016). Rozrobka ploskoyi matematychnoyi modeli rukhu modul'noho trylankovoho prychipnoho avtopoyizda u skladi «avtomobil'tyahach - dvovisnyy pidkatnyy vizok z nepovorotnymy osyamy (dolly) - tryvisnyy napivprychip» [Development of flat mathematical model of motion of the module three-unit towed lorry convoy in composition a «car-tractor is a biaxial pidkatniy light cart with irrevocable axes (dolly) is a triaxial semitrailer]. Naukovi notatky - The Scientific notes, 55, $72-79$ [in Ukrainian].

2. Sakhno, V.P. (2013). Matematychne modelyuvannya trylankovykh avtopoyizdiv v pozdovzhniy, vertykal'niy i poperechniy ploshchynakh [Mathematical modeling of three-axle road trains in longitudinal, vertical and transverse planes]. Visnyk Donets'koyi akademiyi avtomobil'noho transport - Bulletin of the Donetsk Academy of Motor Transport, 3, 73-84 [in Ukrainian].

3. Revin, A.A (1983) Povyishenie effektivnosti, ustoychivosti i upravlyaemosti pri tormozhenii avtotransportnih sredstv [Increase of efficiency, stability and controllability at braking of motor vehicles]. Doctor's thesis. Volgograd [in Russian].

4. Sotskov, D.A. (1988). Povyshenie aktivnoj bezopasnosti avtotransportnih sredstv pri tormozhenii [Increase of active safety of motor vehicles during braking]. Doctor's thesis. Vladimir [in Russian].

5. Pevzner, Ya. M. (1947). Teoriya ustoychivosti avtomobilya [Theory of car stability]. Moscow: Mashgiz [in Russian].

6. Solntsev, A.N. (2004). Sovershenstvovanie protsesa tormozheniya avtopoezda bolshoy gabaritnoy dlinyi [Improvement of the process of braking a road train of large overall length]. Ph.D. thesis. Moscow [in Russian].

7. Stoyanov, G.A., \& Ivanov, V.V, \& Ilarionov, V.A. (1979). Obobschennyiy kriteriy dlya otsenki bezopasnosti dvizheniya avtomobilya pri tormozhenii [Generalized criterion for assessing the safety of vehicle movement during braking]. Avtomobilnaya promyishlennost - Automotive industry, 8, 19-21 [in Russian].

8. Kravchuk, P.M., \& Nilov, R.Yu., \& Babin, Yu.V. (2014). Normuvannya galmivnih vlastivostey kolisnih transportnih zasobiv v Ukraini [Standardization of brake properties of wheeled vehicles in Ukraine]. Naukovo-virobnichiy zhurnal AvtomobIlniy transport: U reallyah mIzhnarodnogo prava - Research and Production Journal Road Transport: In the realities of international law, 2 (238), 8-10 [in Ukrainian].

9. Chudakov, E.A. (1952). Bokovaya ustoychivost avtomobilya pri tormozhenii [Lateral stability of the vehicle during braking]. Moscow: Mashgiz [in Russian].

10. Khamov, I.V. (1989). Povyishenie ustoychivosti legkovogo avtomobilya pri tormozhenii putem primeneniya protivozanosnyih sistem [Increasing the stability of a passenger car during braking by using anti-skid systems]. Moscow [in Russian].

11 Malyugin, P.N. (1985). Vozmozhnosti i puti uluchsheniya ustoychivosti dvizheniya avtomobilya pri tormozhenii [Opportunities and ways to improve the stability of the vehicle when braking]. Ph.D. thesis. Omsk [in Russian].

12. Kolisni transportni zasoby. Vimogi schodo bezpechnostI tehnIchnogo stanu ta metodi kontrolyuvannya [Wheeled vehicles. Requirements for safety of technical condition and control methods] (2011). DSTU 3649:2010 from 01 ${ }^{\text {th }}$ July 2011. Kyiv: Derzhstandart Ukraine, [in Ukrainian].

13. Avtotransportni zasoby. Halmivni vlastyvosti. Terminy ta vyznachennia [Motor vehicles. Brake properties. Terms and definitions]. (1996). DSTU 2886:94 from 01 ${ }^{\text {th }}$ January 1996. Kyiv: Derzhstandart Ukraine, [in Ukrainian]. 
14. Stiikist dorozhno-transportnykh zasobiv. Terminy ta vyznachennia [Sustainability of road vehicles. Terms and definitions]. (1999). DSTU 3736:98 from 01 ${ }^{\text {th }}$ July 1999. Kyiv: Derzhstandart Ukraine, [in Ukrainian].

15. Zasoby transportni dorozhni. Stiikist. Metody vyznachennia osnovnykh parametriv vyprobuvanniam [Means of transport road. Stability. Methods of determining the main parameters of the test]. (1996). DSTU 3310:96 from $01^{\text {th }}$ January 1997. Kyiv: Derzhstandart Ukraine, [in Ukrainian].

16. Yedyni tekhnichni prypysy shchodo ofitsiinoho skhvalennia typu transportnykh zasobiv katehorii $\mathrm{M} \mathrm{N}$ ta $\mathrm{O}$ stosovno halmuvannia [Uniform technical prescriptions concerning the official approval of vehicles of categories M N and O with respect to braking]. (2008). DSTU UN/ECE R 13-09:2002 from $14^{\text {th }}$ January 2008. Geneva: United Nations Economic Commission for Europe.

\section{Handziuk, D. Handziuk Factors affecting the stability of movement of cars and trains in brake mode and criteria for its evaluation.}

Given the increasing intensity of traffic on modern highways, it is necessary to increase the safety of vehicles to avoid accidents that lead to deterioration of human health and significant material losses from damage to vehicles and goods. This issue is especially acute for road trains, the process of movement and braking of which is much more complex than for single cars. It is necessary that the braking system allows you to adjust the speed of the road train in a wide range, counteract skidding, as well as prevent the assembly of the vehicle and its collision with other cars, ie provide adequate stability. The driver must control the behavior of the vehicle while driving and, if necessary, stop it quickly and safely.

Improving the performance of road trains in modern traffic conditions is one of the priority tasks to ensure a high level of safety of their operation with maximum efficiency. Achieving these requirements is possible only if you take into account possible changes in the technical condition of road trains during operation. In particular, considerable attention should be paid to changes that may occur in the braking system of the road train, which can lead to violations of the optimal regulation and distribution of braking forces on the axles and sides of the vehicle, which inevitably leads to loss of stability even at low speeds, especially at maximum load.

In view of this, the analysis of the factors influencing the stability of cars and road trains in braking mode and the main criteria of stability and efficiency of braking of vehicles, as well as a review of regulations governing them.

Keywords: stability, braking mode, braking distance, braking efficiency, specific braking force, steady deceleration, dynamic corridor, lateral sliding, slipping, lane, direction of movement, linear deviation, angular deviation, folding angle.

ГАНДЗЮК Микола Олександрович, кандидат технічних наук, доцент кафедри автомобілів і транспортних технологій Луцького національного технічного університету, е-mail: Gandzyuk64.MG@gmail.com. http://orcid.org/0000-0002-3552-4256.

ГАНДЗЮК Дмитро Миколайович, магістр із спеціальності «Автомобілі і автомобільне господарство», аспірант Луцького національного технічного університету, е-mail: Gandzyukd@gmail.com.

Mykola HANDZIUK, Ph.D in Engeneering, associate professor of automobiles and transport technologies department, Lutsk National Technical University, e-mail: Gandzyuk64.MG@gmail.com. http://orcid.org/0000-0002-3552-4256.

Dmitriy HANDZIUK, Magistr of Transport, Postgraduate Student of Lutsk National Technical University, e-mail: Gandzyukd@ gmail.com.

DOI: $10.36910 /$ automash.v2i15.386 